\title{
Adaptability and stability of soybean cultivars in the region of Chapadões ${ }^{1}$
}

\author{
Helaine Claire Almeida², Abel Pereira Lima Soares ${ }^{2}$, Nerison Luis Poersch ${ }^{3}$, Tarcel Henrique Izidorio², \\ Larissa Pereira Ribeiro Teodoro $2 * \mathbb{0}$, Paulo Eduardo Teodoro ${ }^{3}$
}

10.1590/0034-737X202168040010

\begin{abstract}
Grain yield is a constant concern in soybean breeding programs for being highly influenced by the environment. This trait can be significantly affected by the sowing times. Thus, for the correct cultivar recommendation, methods of stability and adaptability analysis are used to verify the genotype $\mathrm{x}$ environment interaction at different sowing times. In this study, ten soybean cultivars were evaluated in 2016/2017 and 2017/2018 seasons, at different sowing times. Each experiment was carried out in a randomized block design with three replications. The methods of Eberhart \& Russel and Lin \& Binns were used for cultivars recommendation for general, favorable, and unfavorable environments. Cultivars CS2728, BONUS, and BRS1074 show high yield and predictability and therefore are the most suitable for the region of Chapadão do Sul.
\end{abstract}

Keywords: Glycine max; Eberhart \& Russell; Genotype x environment interaction; Lin \& Binns.

\section{INTRODUCTION}

Soybean [Glycine max (L.) Merril] is the most cultivated crop in Brazil. The country accounted for 238.5 million tons of grains in the 2018/2019 harvest (Conab, 2019). The significant increase in soybean yield in Brazil was driven by the development of technology and highpotential genetic materials provided by breeding programs. Compensatory increments and the obtaining of materials of genetic material adapted to the edaphoclimatic conditions of the different Brazilian regions have become necessary (Torres et al., 2015). Soybean is grown in different environments and exposed to different characteristics of soil, temperature, photoperiod, and rainfall. Thus, the effect of genotypes $\mathrm{x}$ environments interaction $(\mathrm{GxE})$ is crucial in cultivars recommendation. For this reason, the search for cultivars with wide adaptation to the different environments has increased due to the dependence on the climatic oscillations at sowing times (Carbonell et al., 2001). To minimize these effects, breeding programs have invested in genotype analysis by performing several trials at the final stages. These trials occur at different locations and times to obtain greater representativeness and reliability in recommending a given genotype for a given region. The use of statistical methods to estimate and explore the GxE interaction is necessary for cultivars recommendation for a given region. The Eberhart \& Russel (1966) and Lin \& Binns (1988) methodologies stand out among the approaches used to analyze this interaction. The Eberhart \& Russel method (1966) is based on the linear regression between the phenotypic value of a given trait based on the environmental index. The environmental index measures the quality of the environment, resulting in positive or negative values, according to its characterization. The predictability of the genotype behavior originates from the component of variance of the deviations of regression,

\footnotetext{
Submitted on July $30^{\text {th }}, 2019$ and accepted on January 09 $9^{\text {th }}, 2021$.

${ }^{1}$ This work is part of the master's thesis of the first author

${ }^{2}$ Universidade Federal de Mato Grosso do Sul, Chapadão do Sul, Mato Grosso do Sul, Brazil. helaineclaire.hca@gmail.com; abelpereiralimasoares@gmail.com; tarcel_izidorio@gmail.com; eduteodoro@hotmail.com

${ }^{3}$ Universidade Federal da Fronteira Sul, Cerro Largo, Rio Grande do Sul, Brazil. nerisonp@yahoo.com.br

*Corresponding author: larissa_ribeiro@ufms.br
} 
classified as stable, moderately stable, or unstable (Cruz et al., 2012).

Lin \& Binns method (1988) weighs the behavioral deviations of cultivars in environments and considers the yield and the relative response of the genotype (Murakami et al., 2004). The method aims at identifying cultivars that maintain the maximum yield in a wide range of environments, using the statistic parameter $\mathrm{P}_{\mathrm{i}}$. The method is easy to interpret and specifies the cultivar recommendation to groups of favorable and unfavorable environments (Cargnin et al., 2008; Peluzio et al., 2008.; Silva et al., 2008).

The methods described above have been used in the recommendation of soybean genotypes for different environments in Brazil (Maia et al., 2006; Silva et al., 2008; Barros et al., 2008; Steiner et al., 2021). This study aimed to investigate the GxE interaction in soybean cultivars grown at different sowing times and use methods of adaptability and stability for soybean cultivars recommendation.

\section{MATERIALAND METHODS}

Five experiments were carried out in the 2016/2017 and $2017 / 2018$ seasons, in the experimental area of Universidade Federal do Mato Grosso do Sul, located at $18^{\circ} 46^{\prime} 26^{\prime \prime S}, 52^{\circ} 37^{\prime} 28^{\prime \prime W}$, with at approximately $810 \mathrm{~m}$ asl, in the municipality of Chapadão do Sul-MS. The sowing times were $11 / 20$ and 12/3/2017 in the first season and 11/ $3,11 / 18$, and $12 / 8$ in the second season. The climate of the region, according to Koppen, is classified as type Aw, defined as tropical humid, with wet summer and dry winter.

Each experiment was carried out in randomized blocks design with ten cultivars and three replications. The experiment used ten cultivars extensively cultivated by the farmers in the region: BRS 1003, BRS 1074, CD 2737 , CD2687, CD 2728, NA 5909, TMG 7962, Geneze 5885, BMX DESAFIO RR, and BMX BÔNUS. The experimental unit consisted of four $5-\mathrm{m}^{2}$ rows, spaced at $0.45 \mathrm{~m}$ between rows. Weeds, pests, and diseases control followed the technical recommendations for the crop. Figures 1 and 2 contain the climatic conditions observed at the sowing times in the 2016/2017 and 2017/2018 seasons, respectively.

Grain yield was evaluated in the central rows of each experimental unit, corrected to $13 \%$ moisture, and extrapolated to $\mathrm{kg} \mathrm{ha}^{-1}$. Data were subject to joint analysis, following the model described in Equation 1:

$Y_{i j k}=\mu+\mathrm{B} / E_{j k}+G_{i}+E_{j}+\mathrm{Gx} E_{i j}+\varepsilon_{i j k}$

Where: $Y_{i j k}$ is the observation in the k-th block, evaluated in the $\mathrm{i}$-th genotype and $\mathrm{j}$-th environment; $\mu$ is the overall mean of the experiments; $\mathrm{B} / E_{j k}$ is the effect of block $\mathrm{k}$ within environment $\mathrm{j}$; is the effect of the $\mathrm{i}$-th genotype, considered as fixed; is the effect of the $\mathrm{j}$-th environment, considered as random; $\mathrm{G} \times E_{i j}$ is the random effect of genotype $i \mathrm{x}$ environment $j$ interaction; $\varepsilon_{i j k}$ is the random error associated with observation $Y_{i j k}$

Scott-Knott test (1974) was applied to cluster the means of the cultivars evaluated. After verifying the significance of the GxE interaction, data were subject to adaptability and stability analyses, using Lin \& Binns (1998) and Eberhart \& Russell (1966) methodologies.

Initially, the environmental indices $\left(I_{j}\right)$ were estimated for each sowing time, according to Equation 2, proposed by Eberhart \& Russell (1966). Negative values of indicate unfavorable environments, while positive values indicate favorable environments.

$I_{j}=\frac{\sum_{i} Y_{i j}}{g}-\frac{\sum_{i} \Sigma_{j} Y_{i j}}{g e}$

Where: $Y_{i j}$ is the yield of the $\mathrm{i}$-th genotype in the $\mathrm{j}$-th enviroment; $g$ is the number of genotypes; $e$ is the number of enviroments. Results are shown in Figure 3.

In the Eberhart \& Russell method (1966), the adaptability is estimated by the parameter $\beta_{l i}$ and the mean yield is estimated by the parameter $\beta_{0 i}$. The stability is calculated from the variance of the deviations of regression $\left(\sigma^{2} \delta_{i}\right)$. These parameters were obtained by the statistical model described in Equation 3:

$Y_{i j}=\beta_{0 i}+\beta_{l i} I_{\mathrm{j}}+\Psi_{i j}$

Where:

$Y_{i j}$ is the mean of genotype $\mathrm{i}$ in enviroment $\mathrm{j}$;

$\beta_{0 i}$ is the linear coefficient of the $\mathrm{i}$-th genotype;

$\beta_{l i}$ is the coefficient of regression that measures the response of the $\mathrm{i}$-th genotype to the variation of environment $\mathrm{j}$;

$I_{\mathrm{j}}$ is the environmental index $I_{j}=\frac{\sum_{j} Y_{i j}}{g}-\frac{\sum_{i} \sum_{j} Y_{i j}}{g e}$;

$\Psi i j$ are random errors, in which each component can be decomposed as $\Psi_{i j}=\delta_{i}+\bar{\varepsilon}_{i j}$, where $\delta_{i}$ is the deviation of regression, and $\bar{\varepsilon}_{i j}$ is the mean experimental error.

The analysis of adaptability and stability proposed by the Eberhart \& Russell method (1966) is based on linear regression, in which genotypes with general or wide adaptability have $\beta_{1 i}=1$; genotypes with specific adaptability to favorable environments have $\beta_{1 i}>1$; and genotypes with specific adaptability to unfavorable environments have $\beta_{1 i}<1$. The stability, calculated by the deviations of regression, considers genotypes with predictable and unpredictable behavior those with $\sigma_{d i}^{2}=0$ and $\sigma_{d i}^{2} \neq 0$, respectively. The hypotheses to be analyzed are $\mathrm{H}_{0}: \beta_{1 i}=1$ versus $\mathrm{H}_{1}: \beta_{1 i} \neq 1$, tested by the test; and $H_{0}=\sigma_{d i}^{2}=0$ versus $H_{1}=\sigma_{d i}^{2}>0$, tested by the F test. All procedures adopted the $5 \%$ of significance level. 
By Lin \& Binns (1988) methodology, the general performance of the genotypes is evaluated based on the lowest estimates of the parameter for each trait, according to Equation 4:

$P_{i}=\frac{\sum_{j=1}^{e}\left(Y_{i j}-Y_{m j}\right)}{2 n}$

Where: $Y_{i j}$ is the grain yield of cultivar $\mathrm{i}$ in environment $\mathrm{j}$; $Y_{m j}$ is the maximum grain yield in environment $\mathrm{j} ; n$ is the number of sowing times $(\mathrm{n}=5)$.

For the favorable $\left(P_{i f}\right)$ and unfavorable $\left(P_{i d}\right)$ environments, the adaptability and stability parameters were estimated according to Equations 5 and 6, respectively.

$P_{i f}=\frac{\sum_{j=1}^{f}\left(Y_{i j}-Y_{m j}\right)^{2}}{2 f}$

$P_{i d}=\frac{\sum_{j=1}^{d}\left(Y_{i j}-Y_{m j}\right)^{2}}{2 d}$

Where:

$f$ is the number of favorable environments; $d$ is the number of unfavorable environments, according to the criterion of Eberhart \& Russell (1966).

All analyses were carried out using Genes software (Cruz, 2013) and followed the procedures recommended by Cruz et al., (2012).

\section{RESULTS AND DISCUSSION}

The analysis of variance for grain yield is shown in Table 1 . The coefficient of variation of $13.87 \%$ reported for yield can be considered as adequate since this is a quantitative trait, i.e., it is highly influenced by the environment. The experimental coefficient of variation is considered as low. According to Carvalho et al. (2003), $16 \%$ is the maximum limit allowed for grain yield in soybean, indicating good control and experimental accuracy.

The significant GxE interaction can be attributed to cultivars that were grown in dynamic environments, where they are exposed to unpredictable climatic factors during the whole development cycle. The accumulated rainfall at each sowing time in the 2016/2017 (Figure 1) and 2017/ 2018 (Figure 2) seasons was higher than that required for
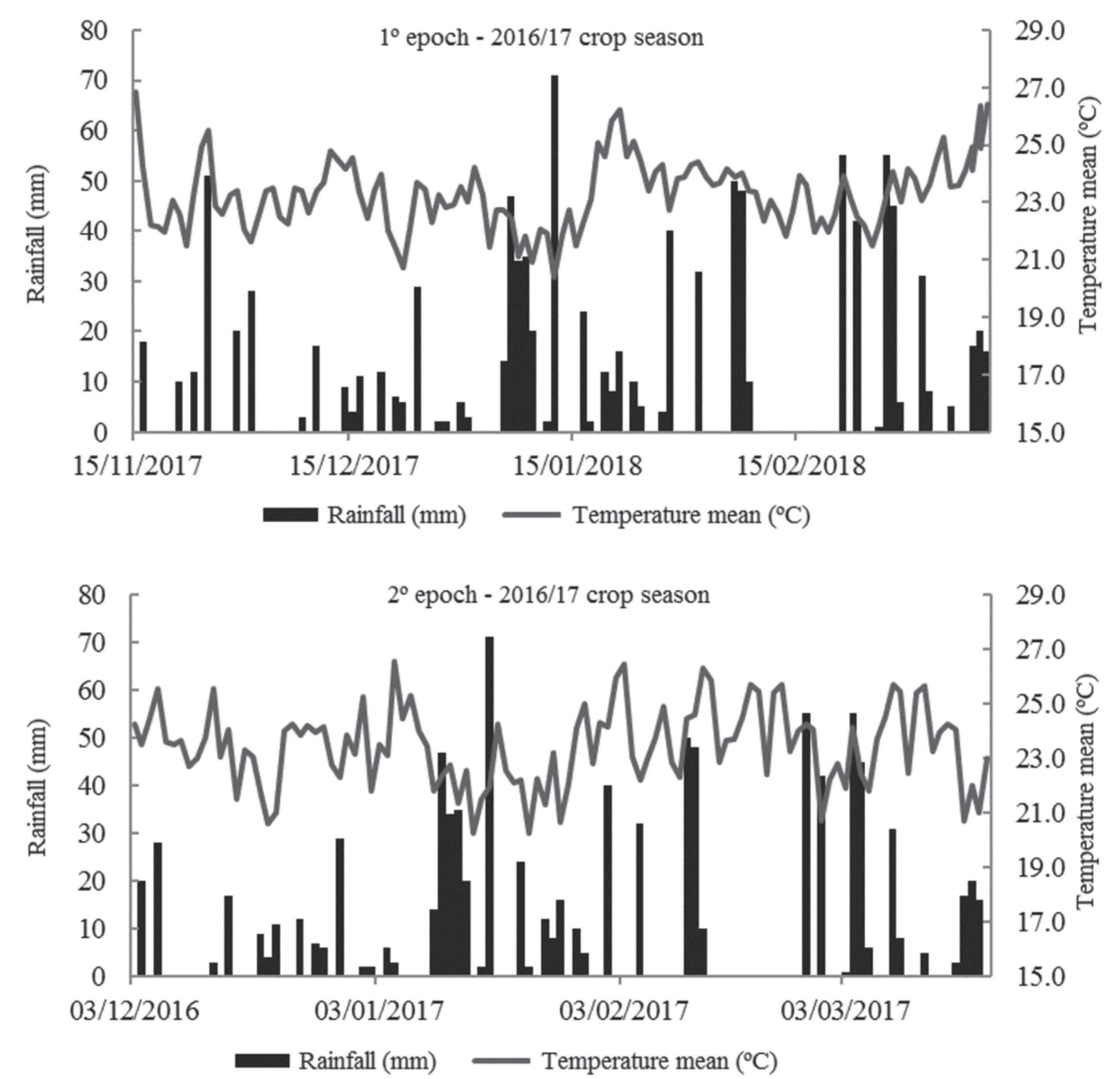

Figure 1: Climatic data of rainfall and temperature from November to February, in the 2016/17 season, for the municipality of Chapadão do Sul - MS.

Rev. Ceres, Viçosa, v. 68, n.4, p. 326-332, jul/aug, 2021 
the soybean crop. However, climatic variations led to different behavior among cultivars. This fact evidences the need for use methods of adaptability and stability for recommendation in the region of Chapadão do Sul.

Among the methods available in the literature, Eberhart \& Russel (1966) and Lin \& Binns (1988) methods stand out in the recommendation of soybean cultivars in different environments (Matsuo et al., 2008; Polizel et al., 2013; Cargnelutti Filho \& Guadagnin, 2018). Figure 3 shows the estimates of the environmental indices obtained by Eberhart \& Russel method (1966) and allow characterizing the quality of the study sites. Negative $I_{j}$ values, i.e., unfavorable environments, identify areas that have adverse conditions to the crop, either due to soil and climatic conditions or the poor technology applied to the crop. Positive $I_{j}$ values, i.e., favorable environments, identify areas that invest in inputs and use adequate technology. In the analysis, environments 11/03/2017 and
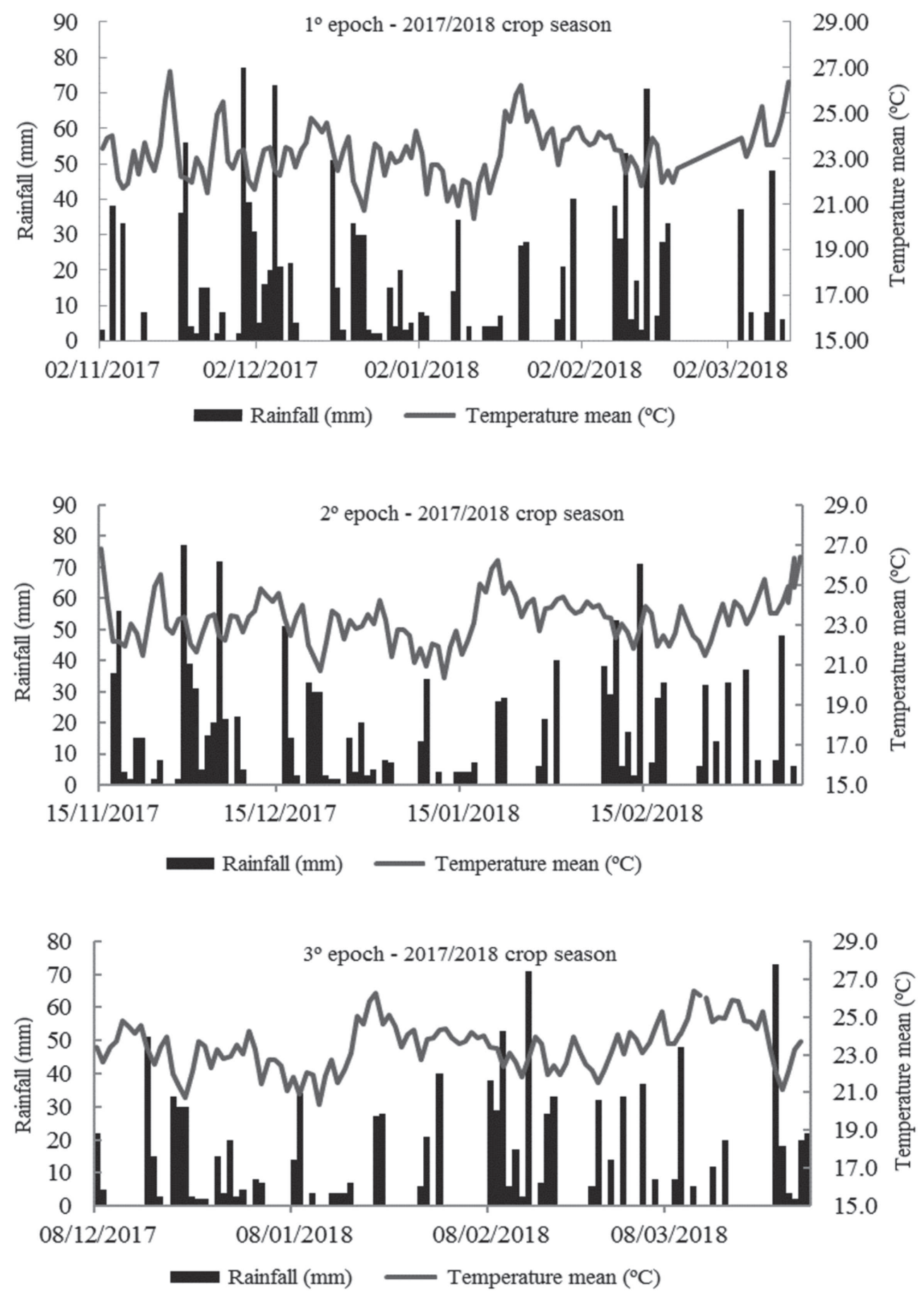

Figure 2: Climatic data of rainfall and temperature from November to February, in 2017/18 season, for the municipality of Chapadão do Sul - MS. 
11/18/2017 led to positive values for the trait evaluated, characterized as favorable and appropriate to the ability of the crop. In these environments, the regular water availability at the vegetative and reproductive stages contributed to this result. The genotypes recommended for these environments must behave responsively to these favorable conditions.

Conversely, environments 11/20, 12/02/2016 and 12/ $08 / 2017$ were classified as unfavorable due to the water deficit recorded at the critical stages of the crop development (Figure 1 and 2). The water deficit was verified during the period of full pod formation and grain filling, which correspond to the phenological stages R4, R5, and R6. In environment 12/08, water deficit was identified at the vegetative stage and at the beginning of flowering, corresponding to the phenological stages V8 and R1. For these environments, genotypes are classified into more rustic and tolerant to the climatic adverse conditions.

Table 2 shows the results based on the Eberhart \& Russell (1966) method, the mean yield $\left(\beta_{0}\right)$, and the parameters of adaptability $\left(\beta_{1}\right)$ and stability $\left(\hat{\sigma}_{d i}^{2}\right.$ and $\left.\mathrm{R}^{2}\right)$ for the soybean cultivars evaluated. Considering these parameters, BÔNUS and TMG 7062 genotypes stand out for their high yield and their specific adaptability for cultivation in favorable environments ( $\beta 1>1)$. BÔNUS reached $80 \%$ of predictability, despite the significant deviation. Considering the ability of the genotype to respond favorably to the environmental stimulus, these cultivars should be used by producers who adopt high level of technology.

The cultivars with a regression coefficient lower than one $\left(\beta_{1 \mathrm{i}}<1\right)$ had low mean yield $\left(\beta_{0}\right)$ and low predictability $\left(\mathrm{R}^{2}<20 \%\right)$. Therefore, among the materials evaluated, the method of Eberhart \& Russel (1966) does not allow cultivars recommendation for unfavorable environments. However, according to the criteria of this method, a general recommendation is possible for sowing times, based on the genotypes with parameter $\beta_{1 \mathrm{i}}$ statistically equal to one. In this sense, cultivars CD 2728 and BRS 1074 are the most suitable to be used at any sowing time in Chapadão do Sul since they had high yield $\left(\beta_{0}\right)$, non-significant deviations, and high predictability.

The criteria for cultivars recommendation by Lin \& Binns (1988) method are shown in Table 3. Genotypes CD 2728, BÔNUS, and BRS 1074 stood out for their high yield and for having lower deviation values in relation to the maximum yield, and thus, they are considered the most stable for general, favorable, and unfavorable environments. Therefore, these cultivars can be

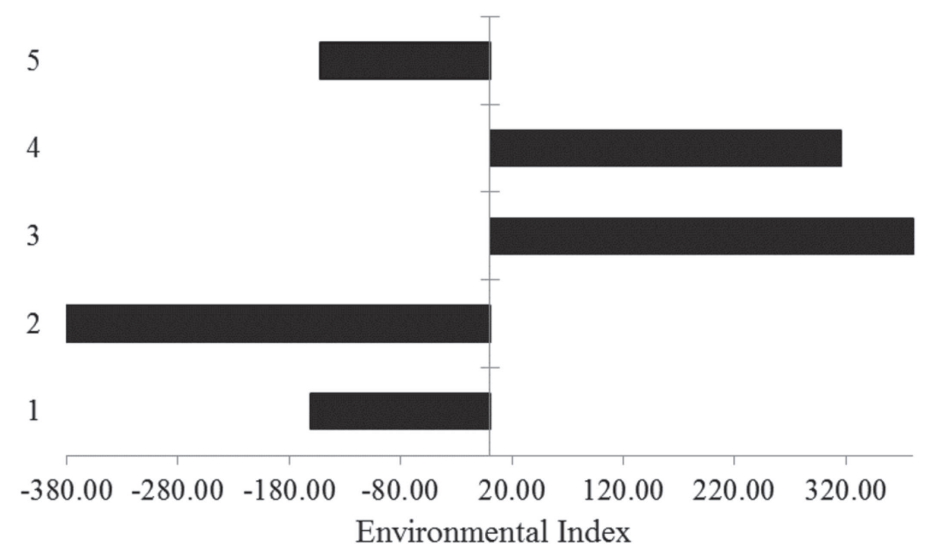

Figure 3: Behavior of soybean genotypes in relation to the trait yield at different sowing times in the region of Chapadão do Sul. Environments 1, 2, 3, 4, and 5 correspond to the sowing times of $11 / 20$ and 12/03 (2016/17 season) and 11/03, 11/18, and 12/18 (2017/ 18 season), respectively.

Table 1: Summary of the analysis of variance for yield of ten soybean cultivars grown at five sowing times, in the 2016/2017 and 2017/2018 seasons, in the region of Chapadões

\begin{tabular}{lcc}
\hline Sources of variation & Degrees of freedom & Mean Square \\
\hline Blocks/Sowing times & 10 & 3301535.63 \\
Cultivars (C) & 9 & $4754326.02^{*}$ \\
Sowing Times (T) & 4 & $407807.29^{*}$ \\
CxE & 36 & $697180.12^{*}$ \\
Residue & 90 & 185492.42 \\
\hline
\end{tabular}

Coefficient of variation $(\%)$

13.87

*: significant and not significant, respectively, by the $\mathrm{F}$ test at $5 \%$ probability level. 
Table 2: Mean yield of ten soybean genotypes $\left(\mathrm{kg} \mathrm{ha}^{-1}\right)$, coefficients of regression $\left(\hat{\mathrm{a}}_{1}\right)$, deviations of regression $\left(\hat{o}_{\mathrm{di}}^{2}\right)$, and coefficient of determination $\left(\mathrm{R}^{2}\right)$ obtained by the Eberhart \& Russel method (1966)

\begin{tabular}{lcccc}
\hline Cultivar & Mean $\left(\boldsymbol{\beta}_{\mathbf{0}}\right)$ & $\boldsymbol{\beta}_{\mathbf{1}}$ & $\boldsymbol{\sigma}_{\text {di }}$ & $\mathbf{R}^{\mathbf{2}}$ \\
\hline CD 2728 & $3812.17 \mathrm{a}$ & $1.34^{\mathrm{ns}}$ & $-57237.98^{\mathrm{ns}}$ & 98.29 \\
NA 5909 & $3216.61 \mathrm{a}$ & $1.04^{\mathrm{ns}}$ & $-4285.16^{\mathrm{ns}}$ & 73.37 \\
BRS 1003 & $2593.88 \mathrm{~b}$ & $-0.09^{*}$ & $174015.12^{*}$ & 0.57 \\
CD 2687 & $2805.92 \mathrm{~b}$ & $0.88^{\mathrm{ns}}$ & $-33902.71^{\mathrm{ns}}$ & 80.43 \\
BONUS & $3662.16 \mathrm{a}$ & $2.44^{*}$ & $156452.44^{*}$ & 80.00 \\
BRS 1074 & $3704.25 \mathrm{a}$ & $1.18^{\mathrm{ns}}$ & $-60878.47^{\mathrm{ns}}$ & 99.53 \\
CD 2737 & $3200.58 \mathrm{a}$ & $1.17^{\mathrm{ns}}$ & $-52689.28^{\mathrm{ns}}$ & 95.63 \\
TMG 7062 & $3352.93 \mathrm{a}$ & $1.78^{*}$ & $55843.45^{\mathrm{ns}}$ & 79.75 \\
GENEZE 5885 & $2589,34 \mathrm{~b}$ & $0,35^{\mathrm{ns}}$ & $9138,55^{\mathrm{ns}}$ & 20,57 \\
DESAFIO & $2113,38 \mathrm{~b}$ & $-0,85^{*}$ & $-43744,38^{\mathrm{ns}}$ & 17,93
\end{tabular}

*, ns: significant and non-significant, respectively, by the $\mathrm{t}$ and $\mathrm{F}$ tests at $5 \%$ probability level.

Table 3: Estimates of phenotypic adaptability and stability of ten soybean genotypes in the 2016/2017 and 2017/2018 seasons, by the Lin \& Binns (1988) method, and the decomposition of (stability and adaptability parameter) into favorable $\left(\mathrm{P}_{\mathrm{if}}\right)$ and unfavorable $\left(\mathrm{P}_{\text {id }}\right.$ ) environments (Lin \& Binns)

\begin{tabular}{lcrrr}
\hline Cultivar & Mean & \multicolumn{1}{c}{$\boldsymbol{P}_{\boldsymbol{i}}$} & \multicolumn{1}{c}{$\boldsymbol{P}_{i f}$} & $\boldsymbol{P}_{i d}$ \\
\hline CD 2728 & $3812.17 \mathrm{a}$ & 14133.64 & 1795.98 & 11692.09 \\
NA 5909 & $3216.61 \mathrm{a}$ & 281917.00 & 37785.86 & 217939.18 \\
BRS 1003 & $2593.88 \mathrm{~b}$ & 1142416.96 & 1740279.73 & 743841.78 \\
CD 2687 & $2805.92 \mathrm{~b}$ & 681575.44 & 904750.39 & 532792.14 \\
BONUS & $3662.16 \mathrm{a}$ & 98625.41 & 0.00 & 164375.68 \\
BRS 1074 & $3704.25 \mathrm{a}$ & 39710.18 & 54444.82 & 29887.09 \\
CD 2737 & $3200.58 \mathrm{a}$ & 288533.01 & 365032.31 & 237533.48 \\
TMG 7062 & $3352.93 \mathrm{a}$ & 185600.60 & 105441.43 & 239040.16 \\
GENEZE 5885 & $2589.34 \mathrm{~b}$ & 1017690.45 & 1379039.85 & 776790.85 \\
DESAFIO & $2113.38 \mathrm{~b}$ & 1824208.04 & -43744.38 & 1243840.42 \\
\hline
\end{tabular}

Mean 3105.12

recommended for Chapadão do Sul. These results are consistent with the genotypes evaluation by the Eberhart \& Russel method, which recommended the same cultivars.

Similar results were found by Romanato et al. (2016) in a study on the phenotypic adaptability and stability of soybean yield in Ceará, and by Marques et al. (2011), in a study on the different sowing times in Uberlândia. The consistency in the use of the methods shown in the present work has also been verified in different crops, such as wheat and maize (Caierão et al., 2006; Cargnelutti Filho et al., 2007), reinforcing their reliability when compared with the use of an isolated method.

\section{CONCLUSIONS}

The Eberhart \& Russel (1966) and Lin \& Binns (1988) methodologies were similar for recommending soybean genotypes.

The genotypes CD 2728, BÔNUS, and BRS 1074 are the most recommended for the region of Chapadões due to their high grain yield and predictability.

\section{CONFLICT OF INTERESTS}

The authors declare no conflicts of interest.

\section{REFERENCES}

Barros HB, Sediyama T, Teixeira RC \& Cruz CD (2008) Análises paramétricas e não-paramétricas para determinação da adaptabilidade e estabilidade de genótipos de soja. Scientia Agraria, 09:299-309.

Caierão E, Silva MS, Scheeren PL, Del Duca LJA, Nascimento Júnior A \& Pires JL (2006) Análise da adaptabilidade e da estabilidade de genótipos de trigo como ferramenta auxiliar na recomendação de novas cultivares. Ciência Rural, 36:11121117.

Carbonell SAM, Filho JA, Dias LAS, Gonçalves C \& Antonio CB (2001) Adaptabilidade e estabilidade de produção de cultivares e linhagens de feijoeiro no Estado de São Paulo. Bragantia, 60:6977.

Cargnelutti Filho A, Perecin D, Malheiros EB \& Guadagnin JP (2007) Comparação de métodos de adaptabilidade e estabilidade relacionados à produtividade de grãos de cultivares de milho. Bragantia, 66:571-578.

Cargnelutti Filho A \& Guadagnin JP (2018) Number of experiments for adaptability and stability analysis in maize by Lin and Binns method. Ciência Rural, 48:e20170130.

Rev. Ceres, Viçosa, v. 68, n.4, p. 326-332, jul/aug, 2021 
Cargnin A, Souza MA \& Fogaça CM (2008) Comparação de métodos de análise de adaptabilidade e estabilidade em trigo. Revista Ceres, 55:243-250.

Carvalho CGP, Arias CAA, Toledo JFF, Almeida LA, Kiihl RAS \& Oliveira MF (2003) Proposta de classificação dos coeficientes de variação em relação à produtividade e altura da planta de soja. Pesquisa Agropecuária Brasileira, 38:187-193.

Conab - Companhia Nacional de Abastecimento (2019) Acompanhamento da safra brasileira: grãos, sexto levantamento, março 2019. Available at: <https://www.conab.gov.br/index.php/infoagro/safras $\geq$. Accessed on: March 30 2019.

Cruz CD, Regazzi AJ \& Carneiro PCS (2012) Modelos biométricos aplicados ao melhoramento genético. Viçosa, Editora UFV. $514 \mathrm{p}$.

Cruz CD (2013) GENES - a software package for analysis in experimental statistics and quantitative genetics. Acta Scientiarum. Agronomy, 35:271-276.

Eberhart ST \& Russell WA (1966) Stability parameters for comparing varieties. Crop Science, 06:36-40.

Lin CS \& Binns MR (1988) A superiority measure of cultivar performance for cultivar $\times$ location data. Canadian Journal of Plant Science, 68:193-198.

Maia MCC, Vello NA, Rocha MDM, Pinheiro JB \& Silva Junior NF (2006) Adaptabilidade e estabilidade de linhagens experimentais de soja selecionadas para caracteres agronômicos através de método uni-multivariado. Bragantia, 65:215-226.

Marques MC, Hamawaki OT, Sediyama T, Bueno MR, Reis MS, Cruz CD \& Nogueira AP (2011) Adaptabilidade e estabilidade de genótipos de soja em diferentes épocas de semeadura. Bioscience Journal, 27:XX-XX.

Matsuo É, Sediyama T, Bandeira Barros H, Cruz CD, Oda MDC \& Teixeira RDC (2008) Análise da estabilidade e previsibilidade da qualidade fisiológica de sementes de soja produzidas em Cristalina, Goiás. Acta Scientiarum. Agronomy, 30:191-196.
Murakami Mitsuyuki D, Cardoso AA, Cruz CD \& Bizão N (2004) Considerações sobre duas metodologias de análise de estabilidade e adaptabilidade. Ciência Rural, 34:71-78.

Torres FE, David GV, Teodoro PE, Ribeiro LP, Correa CG \& Luz Junior RA (2015) Desempenho agronómico e dissimilaridade genética entre genótipos de soja. Revista de Ciências Agrárias, 38:111-117.

Peluzio JM, Fidelis RR, Giongo P, Silva JC, Cappellari D \& Barros HB (2015) Adaptabilidade e estabilidade de cultivares de soja em quatro épocas de semeadura no sul do Estado do Tocantins. Revista Ceres, 55:34-40.

Polizel AC, Juliatti FC, Hamawaki OT, Hamawaki RL \& Guimarães SL (2013) Adaptabilidade e estabilidade fenotípica de genótipos de soja no estado do Mato Grosso. Bioscience Journal, 29:910-920.

Romanato FN, Hamawaki OT, Sousa LB, Nogueira APO, Carvalho Neto DP, Borges CCR, Hamawaki CDL \& Hamawaki RL (2016) Parametric and non-parametric analysis for determining the adaptability and stability of soybean genotypes in three sowing periods. Bioscience Journal, 32:574:580.

Scott AJ \& Knott M (1974) A cluster analysis method for grouping means in the analysis of variance. Biometrics, 30:507-512.

Silva FD, Soares PC, Cargnin A, Souza MD, Soares AA, Cornélio VDO \& Reis MDS (2008) Methods of adaptability and stability analysis in irrigated rice genotypes in Minas Gerais, Brazil. Crop Breeding and Applied Biotechnology, 08:119-126.

Steiner F, Zuffo AM, Teodoro PE, Aguilera JG \& Teodoro LPR (2021) Multivariate adaptability and stability of soya bean genotypes for abiotic stresses. Journal of Agronomy and Crop Science, 207:354-361. 